\title{
Reading the City, Writing the Self: Arabic and Hebrew Urban Texts in Jerusalem, 1840-1940
}

\author{
Yair Wallach
}

One afternoon in October 1908, after a long day of political meetings and private lessons, the teacher and writer Khalil al-Sakakini (1878-1953, fig. 14.1) sat on the balcony of the al-Asma'i newspaper's offices in Jerusalem, near Jaffa Gate. As he noted in his diary, "Officer Jalal Effendi, a member of the Committee for Union and Progress (CUP), passed by. He asked for my visiting card. I wrote on the card that I wished to join the committee and handed it back to him."1 Sakakini, a Jerusalem-born Arab Christian who had been educated in an Anglican missionary school, had just returned from New York with high hopes for the future of the Ottoman Empire after the 1908 Young Turk Revolution. He would soon establish a radically modern school and name it the Constitutional School (alMadrasa al-Dustūriyya). Like other members of Jerusalem's young intelligentsia, he sought to join the revolutionary ruling party. To do so, Sakakini did not write a long letter of motivation or go through interviews; his application consisted of a small piece of card, his visiting card. In giving his card to Jalal Effendi, Sakakini proved himself to be what Stephen Sheehi called one of the Ottoman "new men": worldly, aspiring and modern people, worthy members of a party that sought to radically transform the empire. ${ }^{2}$

Sakakini's visiting card is one example of what I call "urban texts," texts displayed in an urban environment. These texts vary considerably in terms of substance, format, and content. Ephemeral or enduring, fixed or transitory, elaborate or plain, banal or unusual, mass-produced or handcrafted, ancient or recent, these texts take many forms but they all are encountered in urban public settings such as streets, markets, and sites of worship. Textual density is one of the characteristics that distinguishes urban space from rural areas.

1 Khalil al-Sakakini, "Nyu Yurk, Sultana, Al-Quds, 1907-1912" [New York, Sultana, Jerusalem, 1907-1912], in Yawmiyyat Khalil al-Sakakini [Diaries of Khalil Sakakini], vol. 1, ed. Akram Musallam (Ramallah: Khalil Sakakini Cultural Centre; Institute for Jerusalem Studies, 2003), 320-21.

2 Stephen Sheehi, "Portrait Paths: Studio Photography in Ottoman Palestine," Jerusalem Quarterly, no. 61 (2015): 24 .

(C) YAIR WALLACH, 2018 | DOI:10.1163/9789004375741_019

This is an open access chapter distributed under the terms of the prevailing CC-BY-NC-ND License at the time of publication. 
In modern Jerusalem, like in other locales, urban texts functioned within distinctly urban economies of exchange, piety, and power. Collectively, urban texts form a significant corpus, which arguably makes up the majority of texts read by urbanites, and yet is typically understudied. The study of urban textuality is located at the crossroads of several disciplines. Sociolinguists study the "linguistic landscape" of (mostly contemporary) urban signage in multilingual contexts to examine social hierarchies of languages and cross-language influence. ${ }^{3}$ Studies by anthropologists, cultural and art historians have emphasized the historical transformation of textuality and its meaning. ${ }^{4}$

As I show in this chapter, urban texts are a valuable source for social and cultural history: they tell us much about perceptions of communal identities and urban space, the structures of power and their legitimizing discourses. But urban texts are not merely historical sources. My argument is that these texts were tools to achieve radical transformations of state and society in late Ottoman and British Mandate Palestine. Textual media are social technology whose nature is contested and changing. In 1840, texts in Arabic and Hebrew in the urban space were anchored in the word of God. By 1940, text was employed by the colonial state, the Zionist colonial-national movement, Arab nationalism, and a capitalist economy. With modernity, Arabic and Hebrew public texts gained unprecedented presence in urban visual culture but lost their much of their sacred aura. Urban text underwent a process of dematerialization as inscriptions chiseled in stone gave way to posters and cardboard signs.

\section{Textual Citadinité and Sources}

The category of urban textuality invites the question of textual citadinité: in which ways did inscriptions, graffiti, and shop signs contribute to, or undermine, notions and practices of urban citizenship in Jerusalem? Was there a multilingual textual arena of inclusive urban interaction between Arabic, Hebrew, and other languages? Or is it more accurate to speak of parallel writings of the city by separate groups, indifferent or hostile to each other? As this

3 Yasir Suleiman, Language and Society in the Middle East and North Africa: Studies in Variation and Identity (Richmond: Curzon Press, 1999); Elana Shohamy, Eliezer Ben Rafael, and Monica Barni, eds., Linguistic Landscape in the City (Bristol: Multilingual Matters, 2010).

4 Irene A. Bierman, Writing Signs: The Fatimid Public Text (Berkeley: University of California Press, 1998); Brinkley Morris Messick, The Calligraphic State: Textual Domination and History in a Muslim Society (Berkeley: University of California Press, 1993); Juliet Fleming, Graffiti and the Writing Arts of Early Modern England (London: Reaktion, 2001). 
chapter shows, there is no simple answer to these questions. One can point to Jerusalem as a city-cosmos of texts, with instances of urban texts operating across dividing lines. And yet we can also speak of parallel textual economies in isolation or in conflict with each other. With the transition from the late Ottoman inclusive discourse of development and progress to a Mandatory logic of separate communities, urban texts were increasingly understood against the Zionist-Arab conflict and its social ramifications.

The study of historical urban textuality requires a variety of sources, archives, and methodologies. The first question is which texts were visible and to whom. To survey the city's texts, we have to examine the built environment (where urban texts survived in situ), photographic documentation of Jerusalem, ${ }^{5}$ epigraphic collections, ${ }^{6}$ historical ephemera, and others. These sources can give us an idea about which texts were visible in the city, where they were and which languages they were written in. But in order to understand the social significance and operation of texts, we have to look beyond these sources. The crux of this inquiry is the epistemology of text: how Jerusalemites used textual media - traditional and modern alike - to understand and rewrite their world, their city, and themselves. To answer this question, we need evidence of how contemporaries perceived texts, their roles and status. Such evidence may be found in a variety of sources such as historical newspapers, memoirs, and diaries.

In this chapter, I look at two cases of urban text. Sakakini's visiting card is an example of an ephemeral text through which the Palestinian educator crafted his public persona as a humanist intellectual, enthusiastic in his embrace of modernity and the ruptures it entailed. Sakakini used the card to navigate the promises of a progressive post-1908 Ottoman Empire, though it proved to be a short-lived political experiment. The visiting card is mentioned in his diaries as well as in the memoirs of his student Wasif Jawhariyyeh. The diaries and memoirs, published in recent years by the important initiative of

5 On early photography of Jerusalem, see Issam Nassar, Laqatat Mughayira:Al-Taswir Al-Mahalli Al-Mubakkir Fi Filastin, 1850-1948 [Alternative shots: early local photography in Palestine, 1850-1958] (London: Mu'assasat 'Abd al-Muhsin al-Qattan, 2005); Guy Raz, Tsalame ha-'Arets: me-Reshit Yemey ha-Tsilum ve-'ad ha-Yom [Photographers of the land: from early photography to this day] (Tel Aviv: ha-Kibuts ha-me'uhad, 2003). Substantial photographic collections on Jerusalem include the Library of Congress, Central Zionist Archives, the Jewish National and University Library.

6 For Islamic inscriptions, see Archibald G. Walls and Amal Abul-Hajj, Arabic Inscriptions in Jerusalem: A Handlist and Maps (London: World of Islam Trust, 1980). 
the Institute for Palestine Studies, provide a wealth of information for social historians of modern Jerusalem. ${ }^{7}$

My second example is a corpus of Hebrew stone inscriptions in Jerusalem, self-published in the late 1920 s by Ashkenazi Jerusalemite scholar Pinhas Ben Tsvi Grayevsky (1873-1941). ${ }^{8}$ Against the background of the British Mandatory regime and its support of Zionism, the realm of an inclusive urban arena was shrinking. Through the inscriptions, Grayevsky sought to salvage Jerusalem's Jewish communities' heritage at a moment when Hebrew was being reclaimed by a secular, national, and settler colonial project. I am particularly interested in how Grayevsky framed and justified his study.

\section{Sakakini's Visiting Card: The Waltz of Etiquettes}

In the early twentieth century, the visiting card was the most widely used artifact of textual self-representation among western educated elites. Emerging in early modern Europe among the aristocracy, visiting cards were tools through which one gained access to polite society. Cards had to be left in advance in order to arrange visits and be given interviews. There was a strict code regulating their use as part of upper-class etiquette. The word etiquette itself comes from an Old French word meaning "label" or "ticket," perhaps because it describes the process of assigning roles and identities through labelling. ${ }^{9}$ Upper-class etiquette was a rigid system for the regulation of social interaction, prescribing and proscribing the actions of those who moved in high society. Within this system, the visiting card was a vital instrument through which one could present oneself to the reading gaze of others. By the early twentieth century, visiting cards had spread well beyond their European aristocratic origins in terms of class, function, and geography. Cards were widespread among

7 Khalil al-Sakakini, Yawmiyat Khalil Al-Sakakini [Diaries of Khalil Sakakini], ed. Akram Musallam, 8 vols. (Ramallah: Khalil Sakakini Cultural Centre; Institute for Jerusalem Studies, 2003); Salim Tamari and Issam Nassar, The Storyteller of Jerusalem: The Life and Times of Wasif Jawhariyyeh, 1904-1948 (Northampton: Olive Branch Press, 2014).

8 Pinhas M. Ben Tzvi Grayevsky, Sefer 'Avne Zikaron: 'Avne Kodesh bi-Rushalayim [Book of memorial stones: sacred stones in Jerusalem], 15 vols. (Jerusalem: Tzukerman, 1928).

9 Elaine Hernen, "Names Are Everything: For Oscar Wilde, Posing as a Letter and Visiting Card," Vides: MLA Volume of Interdisciplinary Essays 1 (2013), accessed January 17, 2018, https://open.conted.ox.ac.uk/resources/documents/names-are-everything-oscar-wilde -posing-letter-and-visiting-card-elaine-hernen. 
Jerusalem elites, as Maria Chiara Rioli demonstrates in this volume. ${ }^{10}$ The Franciscan Printing Press collection holds 1,500 cards printed between 1880 and 1906, with a wide array of positions and identities, from the Ottoman governor to local midwives. The press was used by all denominations, overwhelmingly by men but also by some women. From instruments for gaining access to the domestic domain, visiting cards became highly charged objects of social capital; circulated, exchanged, and displayed in the public sphere. Stephen Sheehi argues that in early twentieth-century Ottoman Jerusalem, the visiting card cannot be thought of outside the context of Ottoman reforms in education, print media, and land commodification: "the aesthetic of the carte was the aesthetic of the ideology of Osmanlilk modernity and Nahda discourses ... of "progress and civilization."'11 Middle-class professionals and businessmen carefully collected cards they received from others, using them to create a textual map of the people they knew, a kind of catalogue of one's social network, influence, and connection. Like personal portraits, the exchange of cards "tethered individuals to collectives ... and individuals and collectives to institutions and the state."12 Without a card, one could not be read by the world, or in other words, one did not exist as an individual of worth. The card was a textual mask one would wear in public, more important even than clothing and appearance in gaining respectability. The text on visiting cards, while brief and "factual," could communicate one's social standing and make one's status readable to a wider public. In E. M. Forster's 1910 novel Howard's End, the charged encounter between strangers at a concert is mediated through visiting cards. When Leonard Bast is introduced to the Schlegel sisters, he is unsure about their trustworthiness until he looks at their visiting card. The sisters' respectable address in west London - noted by the postcode letter "W" on their visiting card - is sufficient to reassure him..$^{13}$ The social hierarchy of urban residential areas is coded and displayed in the most succinct manner possible. The card allowed its holder to determine her or his own terms of legibility by choosing words, style and, sometimes, photographs. This choice always operated within, or against, the expected norms.

The visiting card stood in contrast to another modern textual artifact: stateproduced personal documents. In the Ottoman Empire, this took the form of the nüfüs tezkeresi, the identity card, a certificate issued on a printed form to

10 See her chapter, "Introducing Jerusalem. Visiting Cards, Advertisements and Urban Identities at the Turn of the 2oth Century," in this volume.

11 Sheehi, "Portrait Paths," 26.

12 Ibid., 31.

13 Edward M. Forster, Howards End (New York: Penguin, 200o), 30. 
every male beginning in the late nineteenth century. Headed with a large tuğrāa, the sultan's emblematic signature, the nüfüs recorded the person's name, date of birth, religion, father, and place of abode, as well as physical description. It was compulsory for every male citizen to hold such a certificate. It had to be presented in a variety of circumstances, including appointments for a government position, dealings with the police, marriage, and real estate transactions. Despite being a personal document, the certificate was not normally obtained directly by the person or his family, but rather through appointed community representatives, the mukhtars. It was no surprise therefore that it was prone to contain spelling errors and incorrect details. ${ }^{14}$ One had little control over the recorded details. In contrast with this mass-produced, officially, and universally prescribed form, the visiting card was a middle- and upper-class document through which the individual had far greater room for self-representation. It was written and phrased by the individual who possessed it, and the choice of languages was similarly a personal decision. The cards in the Franciscan collection varied not only in design, but also in language. Most cards were written in European languages, but cards were also created in Arabic, Ottoman, Hebrew, Armenian, and other languages. Producing one's

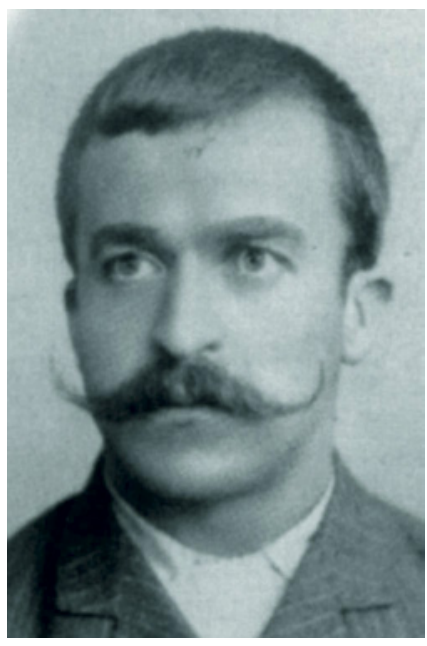

FIGURE 14.1

Khalil Sakakini.

DATE AND PHOTOGRAPHER UNKNOWN, CREATIVE COMMONS.

14 Will Hanley, "Papers for Going, Papers for Staying: Identification and Subject Formation in the Eastern Mediterranean," in A Global Middle East: Mobility, Materiality and Culture in the Modern Age, 1880-1940, ed. Avner Wishnitzer, Liat Kozma, and Cyrus Schayegh (London: I. B. Tauris, 2014). For errors in recording personal details, see the account of Gad Frumkin, Derekh Shofet bi-Rushalayim [The way of a judge in Jerusalem] (Tel Aviv: Dvir, 1954), 106. 
visiting card was similar to producing one's portrait in a photographer's studio. With the turn-of-the-century fashion for photographic cartes de visite, a representative portrait was often featured on the reverse of the card.

A young, aspiring intellectual handing a scribbled visiting card to an army officer on the balcony in the city center: the scene reads like a play in which participants perform a modern ritual in the public gaze. A secret ritual of a very different kind followed it. A day after he forwarded his visiting card with a request to join the CUP, Sakakini was invited to a secret nighttime ceremony during which he was admitted to the party. Blindfolded, his right hand placed on the New Testament and his left on a pistol, he swore that he would defend the constitution and the homeland with his life. The choice of the New Testament in a Muslim-dominated party (for Sakakini was Christian) reflected the secular nature of the new constitutional regime, which rose above religious differences and allowed equality for Christians and Jews. By allowing its members to swear on "their" holy scriptures, without discrimination, the cuP pointed towards making religion a matter for individuals and congregations rather than for the secular state. At the same time, these two artifacts - the holy book and the lethal weapon - instilled a sacred quality in the ceremony. The power of God's word and the power of the pistol underlined the oath Sakakini took, confirming that this was a commitment of life and death. When the blindfold was removed, Sakakini found himself in front of three officers, their faces and bodies covered. The anonymous functionaries who had read his card also observed him in person as he took the oath blindfolded. They represented the new state machinery: impersonal, ideological, and omniscient. The panoptic quality of the ceremony communicated the aspirations of the revolutionized Ottoman state. The CUP promised a place to all citizens, regardless of their religion, but also sought to place them firmly under its gaze.

This quasi-religious nighttime ceremony took place in a house outside the walled city. It should be noted that Jerusalem, as recorded in Sakakini's diaries, is a modern city in which there is no clear distinction between the Old City within the walls and the New City without. Sakakini's professional life revolved around the Jaffa Gate city center, within the walls and outside them. Here he worked, gave private lessons, and socialized in cafes, and it was here that he gave his card to the CUP officer. Sakakini's initiation to the party took place both inside the walls and outside them.

For Sakakini, the visiting card opened the door to the party; his initiation as a party member, on the other hand, required the New Testament. These two artifacts offered radically different roles for textuality. The first was of text as an ever-changing medium of mobility and transformation of self and society. The second was of text as a sacred, unchanging source of stability with power 
of life and death. While Sakakini swore his allegiance on the second text, the scripture receded into the role of a ritual object of faith, while the visiting card assumed an aura of its own, a magical artifact through which one could remake oneself. We do not have the original card Sakakini handed to the CUP, but we know what was written on it. Sakakini's visiting card would later become famous within his social circle. It stated plainly "Khalil Sakakini. A human being, God willing." Sakakini's students, friends, and acquaintances in Jerusalem were familiar with this motto and understood it at once as a statement of simplicity and authenticity, and as an expression of impatience with social pretense and fake conventions. As one of his students wrote: "those who have known [him] can testify that it is hard to describe al-Sakakini with words ... he was loyal and just, and liked everyone to be human in every sense of the word. To this effect, he printed the [aforementioned] statement on his visiting card ... he mocked those who led a manipulative life, and who were many, in his view."15 Sakakini prided himself on his honesty and direct manners, and his willingness to stand by his principles. On numerous occasions, he paid a high personal price for his principles, when he confronted the social consensus and those in power. But the statement "a human being, God willing" was also a rejection of social categorization and labelling. Not only was it a rejection of his own confessional identity as a Greek Orthodox Christian (he was famously excommunicated by the church for his political activism), but it was a sweeping rejection of nationalism and organized religion in general. As he wrote in 1917, shortly before his arrest by the Ottoman police for sheltering an American Jew:

[W]herever I am, I am simply a human being, nothing else. I don't belong to political parties or religious factions. I consider myself a patriot wherever I am, and strive to improve my surroundings whether they are American, British, Ottoman or African, whether they are Christian, Muslim or pagan. I only work to serve knowledge, and knowledge has no homeland. What is a patriot? If being a patriot means to be sound of body, strong, active, enlightened, moral, affable and kind, then I am a patriot. But if patriotism means favouring one school over another and showing one's brother hostility if he is from a different school or country, then I am no patriot. ${ }^{16}$

15 Tamari and Nassar, The Storyteller of Jerusalem, 152.

16 Quoted in Salim Tamari, “Khalil Sakakini's Ottoman Prison Diaries," Jerusalem Quarterly, no. 20 (2004): $7-23$. 
With his strong belief in humanism, and his equally strong Jerusalemite identity, Sakakini was the embodiment of Jerusalemite nonsectarian, urban citizenship. Describing himself as a human being was a rejection of the social identities imposed by groups, nations, and creeds. But "human being" is not to be understood as the authentic kernel hiding beneath the false layers of imposed identities. Rather, for Sakakini, humanist simplicity itself was a product of rigorous self-fashioning, an attestation of his commitment to Enlightenment values and his individualistic outlook. "Human being" was not a description but an aspiration, a pledge, a call to arms, as Sakakini made obvious by the suffix "God willing." Being human was not a given, but something to be achieved. Sakakini's self-definition as a "human being", and nothing else, became part of his lifelong project of fashioning himself as a modern individual, much of it inspired by his admiration of Western culture. This selffashioning involved a strict daily regime of exercise, cold showers, a vegetarian diet, and obsessive writing and reading. This was a continuous disciplining of body and soul, of self-articulation through constant writing of thousands of pages in diaries and letters, as well as published articles and books including a draft of his own obituary. The role of Jerusalemite humanist writer and educator was the most important role Sakakini played, and the one he performed throughout his adult life alongside the many other identities and ideas he adopted and rejected, always with fervor and great excitement. As his contemporaries attested, Sakakini was a deeply theatrical person who enjoyed performing in front of friends and colleagues. A "human being" was not the naked truth hiding behind a social mask: it was a mask in itself. Sakakini's visiting card was the textual manifestation of this mask: a statement of simplicity and humility, but also a carefully worded, publicly proclaimed ideological persona. It was this humanist mask that Sakakini chose to wear in public, circulating it to friends and colleagues in the form of his visiting card.

Sakakini was apparently soon disillusioned with the CUP, and he does not mention in the diaries any further activities within the framework of the local party, nor any sense of affiliation to it. By the First World War, his diary documents severe criticism of the CUP-led Ottoman government and its repressive measures against the population. His 1908 accession to the party captured a moment of optimism among the "new men" of the Ottoman Empire, the burgeoning middle class of professionals rising to claim a role in economy and decision-making. Yet as Bedross Der Matossian points out, the enthusiasm soon dissipated, especially among national and ethnic groups who felt they had been denied a place in the centralized CUP machinery. ${ }^{17}$

17 Bedross Der Matossian, Shattered Dreams of Revolution: From Liberty to Violence in the Late Ottoman Empire (Stanford: Stanford University Press, 2014). 
When British forces arrived in Jerusalem in 1917, the local sense of urban citizenship was at its zenith. The shared predicament of the war created strong bonds of cross-confessional urban solidarity. Perhaps the most famous example of this solidarity is Sakakini's aforementioned decision to give shelter to an American Jew fleeing Ottoman intelligence; both were arrested and exiled to Damascus. ${ }^{18}$ This sense of solidarity was soon to change. The establishment of the British Mandate over Palestine and its commitments to the Zionist movement led to an inevitable clash between the Arab indigenous majority and the Jewish communities, both local and migrant-settlers alike. This conflict severely undermined the possibility of a nonsectarian, locally-defined, inclusive sense of belonging. The upheaval disrupted Arab-Jewish relations, but it also turned upside down the structures of local Jewish communities. The diverse Ottoman Jewish communities were replaced by a Zionist-led Jewish Yishuv. This transition was reflected in the Hebrew textual landscape of Jerusalem and is captured in Grayevsky's mammoth project to document the city's Hebrew stone inscriptions. At a time when Sakakini was embracing the future, Grayevsky wanted to salvage the past. Sakakini's unreserved embrace of new textual artifacts and the social transformation they entailed stands in contrast to Grayevsky's desperate attempt to preserve traditional textual artifacts in a world of uncertainty and turmoil.

\section{Salvaging Hebrew Stone Inscriptions: Engraved Memories}

A Jewish Jerusalemite intellectual contemporary of Sakakini's, Grayevsky was far less well-known. ${ }^{19}$ It is doubtful if the two ever met. Unlike Sakakini, Grayevsky received no formal Western education, and was schooled in an Ashkenazi yeshiva. However, a keen autodidact, he managed to expand his horizons beyond Orthodox literature. Born and raised in the Ashkenazi confines of Jerusalem to parents who immigrated from Belarus, he worked as a teacher of Talmud and a clerk in a Jewish hospital and probably never travelled away from Palestine. Grayevsky was rooted in the Ashkenazi society in

18 Tom Segev, One Palestine, Complete:Jews and Arabs under the British Mandate, trans. Haim Watzman (London: Little, Brown, 2000), 13-32.

19 Although many of Grayvesky's prolific publications have been used by historians such as Yehoshua Ben-Arieh, there is no study of his overall œuvre. On Grayevsky as an Orthodox historian, see Kimmy Caplan, "Trends and Characteristics in the Study of Orthodoxy in the Israeli Academy," Zion 74 (2009). 
Palestine that developed in the nineteenth century through migration from eastern Europe. It was a society that remained embedded and dependent on eastern European networks of charity, patronage, scholarship, and commerce. This milieu was conservative in outlook and is generally seen as having been hostile to ideas of Jewish enlightenment (the Haskalah). And yet Grayevsky was inspired by ideas of Hebrew cultural revival and Jewish settlement and immigration. As a local Jerusalemite, self-taught Orthodox maskil and proto-Zionist, Grayevsky shows the relative fluidity among Jerusalem's late Ottoman Jewish communities, often missed in the historiography's misleading dichotomies of "Old" and "New" Yishuv.

In November 1917, the British government issued the Balfour Declaration, and five weeks later British forces occupied Jerusalem. Local Jewish communities found themselves in a new and confusing situation. The local Jewish establishment was swept aside by the newly arrived Zionist leadership. The World Zionist Organization was legally recognized by the authorities as the representative of Jews in Palestine, and its officials left very little room for local Jewish elites. Against this backdrop, in the 1920 s and 1930s, Grayevsky authored no fewer than 170 booklets chronicling the history of Jerusalem's Jewish - mainly Ashkenazi - communities. His work is a curious mix of pietistic local scholarship, antiquarian fascination, and protonational historiography. Driven by his motivation to ensure the legacy of the Orthodox Ashkenazi communities in Jerusalem, he attempted to write them into the story of "Jewish revival" in Palestine. By stressing the active Orthodox role in the growth of the Yishuv, Grayevsky was offering an alternative narrative to the dominant Zionist one, which depicted Palestine's local Jewish communities as reactionary, diasporic in character, and unproductive.

In 1928, following the 1927 Palestine earthquake, Grayevsky set out on a mammoth project to collect and document Hebrew stone inscriptions in Jerusalem in a multivolume book called Stones of Memory. ${ }^{20}$ Self-published and funded by donations, this fifteen-volume series was far from a rigorous scientific enterprise, as Grayevsky himself acknowledged in his apologetic introduction. Unlike epigraphic conventions, the corpus was organized not by inscription date but by location. Jumping between sites in an erratic manner, the collection is eclectic in its focus and commentary. In the introduction to the series, Grayevsky explained his motivation for the project: 
Because of their antiquity, some of the [stones] are already broken, their letters disappearing. Others have been rendered over with lime and plaster so the inscriptions are no longer visible. Yet others I have had to scrub, clean and wash until I could read them. And some are no longer in their original place ... To save them from the ravages of time, and to revive their memory, I have, with God's help, undertaken the job of copying and publishing them in a book for eternal memory. ${ }^{21}$

The name of the series, Stones of Memory, recalls other books of the same title that collected burial inscriptions from Jewish cemeteries in Toledo, Frankfurt, and other places. These books aimed to ensure eternal memory for those buried and to allow readers to pray for them. Indeed, volumes 8 to 14 of Grayevsky's series consist of epitaphs in Jewish cemeteries in Jerusalem, Jaffa, and some Zionist colonies, with full names and dates of burial. The bulk of the work, however, was a survey of foundation and commemoration stones of Jewish institutions such as hospitals, old age homes, and synagogues. The first seven volumes of the series list nearly two thousand inscriptions from Jerusalem. In a clear aberration from the Jewish memorial genre, Grayevsky also included ancient inscriptions excavated in Jerusalem by archaeologists, not only in Hebrew but also in Greek and Latin. He listed Islamic inscriptions from Jerusalem and Hebron and Samaritan inscriptions from the synagogue near Nablus, which he received through his communications with Muslim and Samaritan religious scholars. He included endorsements from these scholars in his publications.

The interesting eclecticism of Grayevsky's enterprise points towards an inclusive textual imaginary that acknowledges formal and semantic similarities between Islamic and Jewish inscriptions. Although Grayevsky's focus was on Hebrew inscriptions, he made it clear that his interests in Jerusalem's textual landscape were broader. But what kind of common denominator was there between these different inscriptions? The collection pointed to two possible understandings of nonsectarian commonalities. The first was the similarities and mutual respect between Abrahamic religions, as indicated by Grayevsky's expressed gratitude to the Muslim and Samaritan religious scholars. The second possible commonality was a shared interest in the scientific study of the past and especially the study of inscriptions (epigraphy) as a Western science. The inclusion of archaeological discoveries in Jerusalem pointed in that direction. Despite his admitted shortcomings, Grayevsky hoped to contribute to a scientific discourse and the scholarly production of historical knowledge.

21 Ibid., 3. 


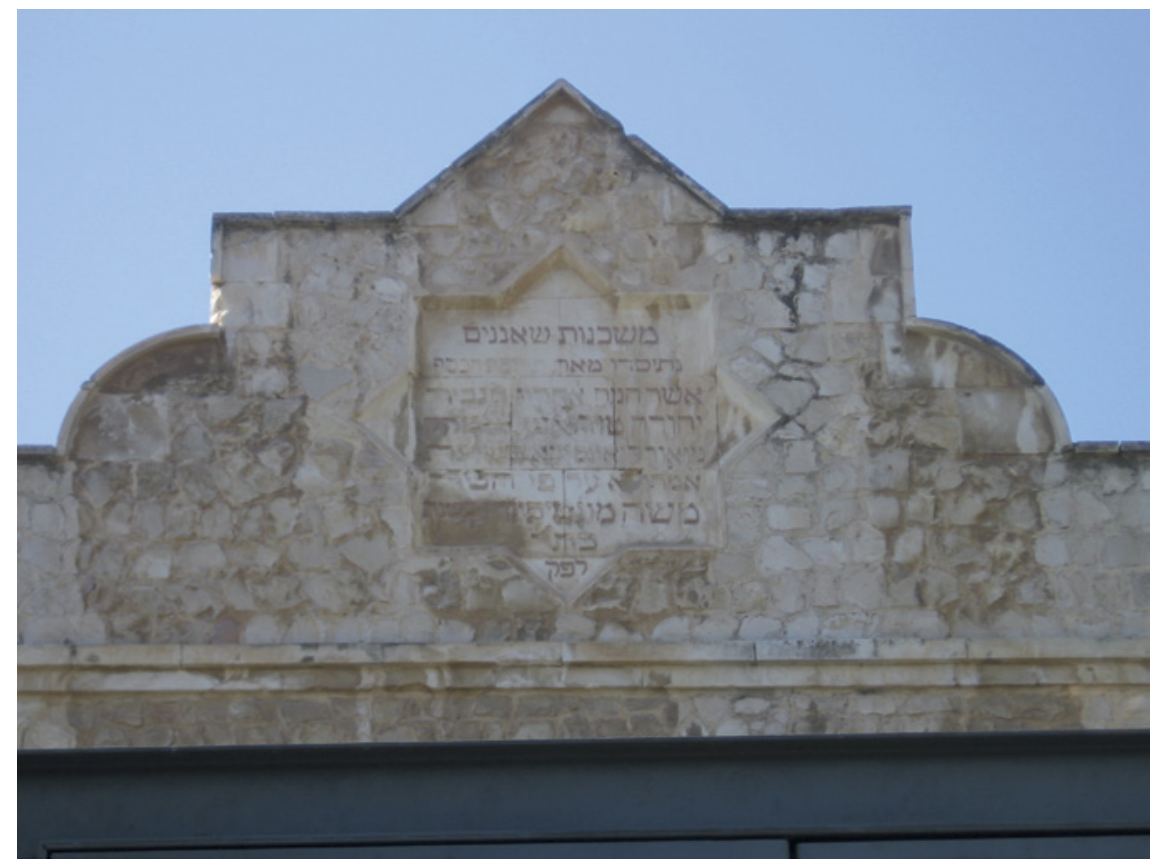

FIGURE 14.2 Dedication inscription of the Mishkenot Sha'ananim alms houses outside Jaffa Gate, built in 1860. This was among the earliest Hebrew dedication inscriptions in Jerusalem.

YAIR WALLACH, 2006.

These two options - Abrahamic respect and reverence, or alternatively, a common belief in European scientific study - provided two dissimilar directions for an inclusive intellectual production that could bind Hebrew inscriptions with Islamic ones, and a Jewish scholar with his Muslim and Christian counterparts. And yet it was clear that such Jerusalemite alliances were secondary to Grayevsky's main interest, which lay firmly within the emerging Jewish society in Palestine. In his introduction, Grayevsky presented the inscriptions as vital historical sources, carrying a "wealth of information" on the early history of community leaders and donors who built the Yishuv from the "ruins" of Jerusalem. The book's hagiographic account of these benefactors aimed to insert Jewish donors and pious community leaders into the national narrative of Jewish "revival" in Palestine.

Grayevsky's description of the "antiquity" of Hebrew inscriptions notwithstanding, the memorial stones he documented were in fact not ancient at all. In a corpus of nearly two thousand inscriptions, only ten dated before 1850. Two-thirds of the dated inscriptions were erected after 190o. This is not 
surprising given the modern history of Jews in Jerusalem. Up until the 1830s, Jerusalem had no more than two thousand Jews, constituting less than a quarter of the city's population. The sixteenth-century Sephardic ben Zakay Synagogue complex was the only recognized Jewish house of prayer in the city. ${ }^{22}$ Correspondingly, Hebrew inscriptions were almost nonexistent in the city's streets. This state of affairs changed dramatically in the coming decades. Rapid Jewish immigration, mostly from eastern Europe, but also from North Africa, central Asia, and other parts of the Middle East, was transforming the city. By 1910, the number of Jews had risen to forty-five thousand, composed of an Ashkenazi majority, a large Sephardi community, and smaller Mizrahi congregations. ${ }^{23}$ There were now hundreds of new synagogues and religious schools in the city, and a prominent element in all of them were stone inscriptions commemorating individuals who donated to the construction, repair, or upkeep of these institutions. As late as the 1910s, these inscriptions were the dominant form of monumental public writing in Hebrew, and they were visible throughout the city. No real difference can be detected in inscriptions in the Old City and extramural neighborhoods: in visual and textual format, date and use, most inscriptions were almost identical.

The act of placing the inscription was given great importance. The memorial stone at the entrance to the main Ashkenazi Synagogue, Ha-Hurva, built between 1857 and 1864, was erected long before the completion of the building. The elders "remembered their promise to the charitable Yehezkel Re'uven [a Baghdadi Jew], to fix above the synagogue's lintel a large stone commemorating his great benevolence to the Ashkenazi congregation by building this synagogue." 24 Chiseled deep into heavy stones and painted routinely to ensure their visibility, the inscriptions promised the benefactors' name would be displayed forever in the Holy City. Jewish institutions typically relied on many donors rather than a single patron. When the money to build the Ha-Hurva

22 The small heterodox Karaite community used an older, tenth-century synagogue. See Yoram Erder, "The Mourners of Zion: The Karaites in Jerusalem in the Tenth and Eleventh Centuries," in Karaite Judaism: A Guide to its History and Literary Sources, ed. Meira Polliack (Leiden: Brill, 2003).

23 Yehoshua Ben-Arieh, Jerusalem in the Nineteenth Century: Emergence of the New City (New York: St. Martin's Press; Jerusalem: Yad Izhak Ben-Zvi, 1986), 241; Uziel O. Schmelz, 'Ukhlusiyat-Yerushalayim: Temurot ba-'Et ha-Hadasha [Modern Jerusalem's demographic evolution] (Jerusalem: Jerusalem Institute for Israel Studies, 1988), 17.

24 David Kroyanker, "Ha-Beniya ba-Ir ha-'Atika" [Jerusalem architecture: the Old City] Adrikhalut Bi-Rushalayim 6 (Jerusalem: Keter, 1993), 191. 
Synagogue ran out, fundraisers were sent to Europe to "sell" the windows of the synagogue to donors, and the window lintels were full of names. ${ }^{25}$

Many inscriptions were visible, if not legible, to a wider urban population passing by regardless of religious or ethnic identity. And yet it is clear that the primary function of these texts was within Jewish communal circles, defining ethnic and religious boundaries. Jews in Jerusalem were fragmented in dozens of communities, differing in cultural praxis, occupations, organization, oral tradition, and areas of residence. The congregational affiliation was often mentioned explicitly or implicitly in the inscription. There were instances of cross-ethnic support and charity, such as the Ha-Hurva Synagogue mentioned above, where an affluent Jewish Baghdadi patron donated to an Ashkenazi synagogue, where his family would not normally pray. But in most cases, support came from within the relevant ethnic congregation and its own support network, extending far and wide. The overwhelming majority of inscriptions commemorated overseas benefactors. From Bialystok to Newark, Bombay to $\mathrm{Fez}$, Jewish donors claimed a space in Jerusalem, extricating the city from its immediate locale. The Hebrew inscriptions made Jerusalem sites into nodes in global networks of piety, a complicated constellation of ethnic and religious communities. Hebrew functioned in these inscriptions as a common sacred language, binding a wide array of local congregations with worldwide Jewish diasporas. It protected and enshrined pious institutions of prayer, learning and welfare, and the memory of their benefactors. The inscriptions were neither national nor colonial; they did not invoke a mythical biblical past or lay national claim to these sites and to the city.

Stones of Memory portrays the dramatic appearance of Hebrew in the urban space of Jerusalem in the second half of the nineteenth century. As such, Grayevsky's description of the stones as "ancient" appears strange and misleading. I suggest this description referred not to the actual inscriptions but to the medium of inscriptions. By the 1920s, memorial inscriptions were becoming "history," an anachronistic mode of commemoration. The 1927 earthquake, which destroyed many buildings and prompted Grayevsky to record these inscriptions, highlighted their physical vulnerability. And yet more damaging to the longevity of the stones was the political, social, and cultural earthquake of Zionism. The communities the inscriptions spoke to and for-communities, which mostly arrived in the nineteenth century - found themselves challenged by a new kind of Jewish community, identity, and culture, whose approach to Hebrew was an abrupt disruption of longer textual traditions. Rather than a sacred tongue of a global network of communities, the Zionist movement

25 Ibid. 
presented a bold vision of the Hebrew language as a secularized tongue of a nation "like all other nations." It used Hebrew to rewrite the landscape of Jerusalem in a dramatic project of remaking land and people. Zionist activists celebrated shop signs in Hebrew, lobbied British authorities to display Hebrew signs on government buildings, demanded the use of Hebrew in telegrams, and erected street name plates in Hebrew. They cared little for grassroots commemoration: their textual practice was tied to the settler ethos of claiming the land and denying its recent history - even its recent Jewish history. Grayevsky's corpus was a desperate attempt to salvage the stones and their inscribers by

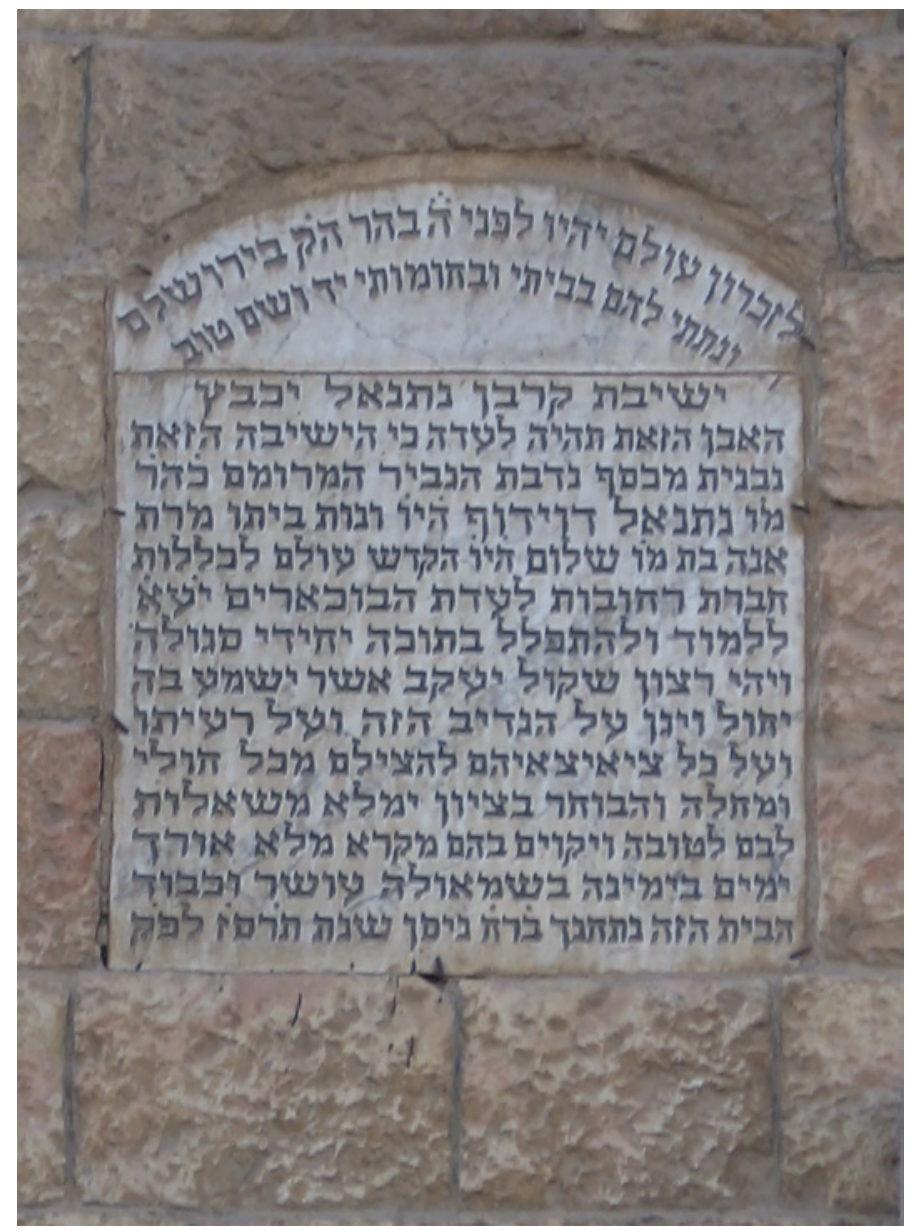

FIGURE 14.3 Dedication inscription of the Jewish religious seminary (yeshiva) in the Bukharan Quarter, built in 1927.

YAIR WALLACH, 2006. 
writing them into the Zionist narrative. But his project failed: nothing proves this better than the fact that his remarkable corpus was entirely ignored by subsequent Jewish historians of Jerusalem.

\section{Conclusion: Between Textuality and Temporality}

Sakakini's visiting card and the Hebrew stone inscriptions were very different forms of urban textuality. Sakakini's card was an ephemeral piece of card, displayed only in specific moments of encounter; the heavy stone inscriptions were affixed to specific locations, visible to many but read by few. Yet both of these forms were texts visible in the urban realm of modern Jerusalem. Both of these examples were produced in the early twentieth century, and both operated against the tension of competing frameworks of textuality: the pious, sacred text and the modern, transitory one.

Sakakini's Ottoman Jerusalem was a modern city full of promise for development, freedom, and progress. His nonsectarian humanism relied on a fresh rewriting of the city and its people, in an Ottoman Empire that, after 1908, appeared to offer civic liberties regardless of confessional and ethnic identity. Grayevsky saw Mandatory Jerusalem through the prism of traditional pious Jewish congregations. Against British support for Zionism and the Mandatory perception of Jerusalem as a polarized city, local Jewish communities attempted to define their place within a Zionist narrative, rather than a Jerusalemite or Palestinian one. Grayevsky's Jerusalem was very different to Sakakini's, and yet it is interesting to note that both these cities extended inside and outside the walls. The sharp distinction between the sacred "Old City" and the modern "New City," which was a cornerstone of British urban planning, is not found in the two men's writing.

When writing social history, urban texts present themselves as a rich and largely untapped corpus. Increasingly surrounded by urban texts of new kinds, urban subjects in early twentieth-century Jerusalem came to understand and define themselves and their world through what they read - advertisements, shop signs, name plates, and business cards. New textual media facilitated new modes of subjectivity, as people defined themselves through reading and writing in Arabic and in Hebrew. Sacred textuality, firmly anchored in divine order, was sacrificed in favor of a new textuality of flux, promising personal and social emancipation. New signs unsettled religious communities and created crisis and displacement, foreshadowing an open-ended process of renaming and redefinition, not only of buildings but also of subjects, through artifacts such as the visiting card. As Grayevsky's case shows, this could raise a series of 
questions regarding "traditional" uses of sacred languages. As Sakakini's case shows, ephemeral, urban texts were means to write the city and oneself. Both writers - Sakakini the modernist and Grayevsky the "traditionalist" - sensed the crisis of text and its wider social and political manifestations. Questions of textual validity and the link between sacred language and its modern incarnation are present in the stories of both these very different men. 